Georgetown University Law Center

Scholarship @ GEORGETOWN LAW

1982

\title{
Conditioning U.S. Security Assistance on Human Rights Practices
}

Stephen B. Cohen

Georgetown University Law Center, cohen@law.georgetown.edu

This paper can be downloaded free of charge from:

https://scholarship.law.georgetown.edu/facpub/1592

Stephen B. Cohen, Conditioning U.S. Security Assistance on Human Rights Practices, 76 Am. J. Int'I L. 246 (1982)

This open-access article is brought to you by the Georgetown Law Library. Posted with permission of the author. Follow this and additional works at: https://scholarship.law.georgetown.edu/facpub

Part of the International Law Commons 


\title{
GONDITIONING U.S. SEGURITY ASSISTANCE ON HUMAN RIGHTS PRACTICES
}

\author{
By Stephen B. Cohen*

\section{INTRODUCTION}

The level of parliament depends on whether it does not merely discuss great issues, but decisively influences them; in other words, its quality depends on whether what happens there matters, or whether parliament is nothing but the unwillingly tolerated rubber stamp of a ruling bureaucracy.

Max Weber

In the United States, with its government of separated powers and functions, it is the executive branch, and in particular the Department of State, that bears responsibility for implementing legislation on foreign relations. The success of implementation will depend on political decisions, involving competing national interests, as well as on institutional and personal considerations of the officials concerned. Inevitably, there is a gap between legislation and execution, especially when the Executive is not wholly sympathetic to the law. The gap may even devour legislated policies as the Executive refuses "to take Care that the Laws be faithfully executed,"2 and bureaucratic and personal considerations distort judgments, exploit the generality and uncertainty of language, and lead to abuse of discretion. A notable instance of this problem has been executive implementation of legislation on international human rights.

The international law of human rights imposes obligations on governments in the exercise of their domestic sovereignty. Under the Universal Declaration, the United Nations Covenants, the European and Inter-American Conventions, and the Helsinki accords, states have defined and agreed to respect certain basic freedoms of persons within their jurisdiction. ${ }^{3}$ These obligations suggest a corresponding duty of one government not to support another engaged in serious violations of internationally recognized human rights. In the world of states,

* Associate Professor of Law, Georgetown University Law Center; formerly Deputy Assistant Secretary of State for Human Rights and Security Assistance (1978-1980; see infra note 14). This article is based on a study prepared for the International Human Rights Law Group of the Procedural Aspects of International Law Institute, under a grant from the Ford Foundation.

The author is indebted to a number of current and former Department of State officials who reviewed this article. In addition, Richard Bilder, Barry Carter, Joel Handler, Richard Lillich, Michael Seidman, Don Wallace, Edith Weiss, Amy Young-Anawaty, and Karen de Young generously provided comments. Janet Milne gave editorial advice with each new draft. Jeff Turner furnished invaluable research assistance.

${ }^{1}$ M. WEBER, Parliament and Government in a Reconstructed Germany, in 2 ECONOMY AND SOCIETY 1392 (1978).

2 U.S. CONST. art. II, $\$ 3$.

${ }^{3}$ See R. Lillich \& F. Newman, InTernational Human Rights: Problems CF LAW aNd POLICY (1979); L. SOHN \& T. BUERGENTHAL, INTERNATIONAL PROTEGTION OF HUMAN RIGHTS (1973). 
the enforcement of international obligations depends on the recognition and implementation of such a duty. While its contours have yet to be articulated under international law, this duty has already been the subject of domestic American statutes that set forth rules for the Executive's conduct of foreign relations with repressive governments. This article examines the legislationin force since 1973-that conditions a foreign government's eligibility for United States military aid and arms sales on its human rights record. ${ }^{4}$

Congress believed this legislation to be required by American self-interest, as well as supported by principles of international law. The gift of aid and the sale of arms, it is true, can promote important national security objectives of the United States. ${ }^{5}$ In addition to enhancing the defense capability of friendly countries, military ties give the United States influence with and access to other governments. ${ }^{6}$ Yet governments to which the United States sends military aid and arms are viewed, by their own people and by the world community, as in part sustained and even approved by us. When the government in question is repressive, the perception of American support for it can impose considerable costs for American interests. The government may be overthrown and the supply of American aid and arms deeply resented by its successors. ${ }^{7}$ The support of repressive governments also conflicts with traditional American values and damages the international reputation of the United States because of the appearance of complicity in repugnant practices. ${ }^{8}$

The principal (although not exclusive) legislative enactment on human rights and military ties has been section 502B of the Foreign Assistance Act of $1961 .^{9}$ The key subsection of this statute, $502 \mathrm{~B}(\mathrm{a})(2)$, provides a basic rule: military aid is not to be given and arms are not to be sold to "any country, the government of which engages in a consistent pattern of gross violations of internationally recognized human rights." 10 An exception is allowed for cases where "extraordinary circumstances exist which necessitate a continuation of [military aid and

\footnotetext{
${ }^{4}$ At the same time, Congress also enacted legislation to establish human rights criteria for programs of economic aid. For example, under section 116 of the Foreign Assistance Act of 1961, the President may not provide development assistance "to the government of any country which engages in a consistent pattern of gross violations of internationally recognized human rights." 22 U.S.C. $\$ 2151$ (n (Supp. III 1979). For a comprehensive review of all the human rights legislation enacted since 1973, see Weissbrodt, Human Rights Legislation and U.S. Foreign Policy, 7 GA. J. INT'L \& COMP. L. 231 (1977). For a catalog of all statutes on human rights and foreign policy, see R. Lillich, U.S. Legislation Relating Human Rights to U.S. Foreign Policy (1980) (available from International Human Rights Law Group, Washington, D.C.).

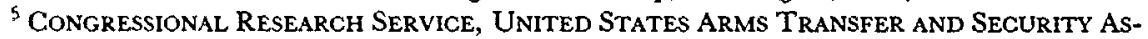
Sistance Programs: Prepared for the Subcomm. ON Europe and the Middle East of The House Comm. on International Relations, 95th Cong., 2d Sess., at xi (Comm. Print 1978) [hereinafter cited as CRS, SECURITY ASSISTANCE STUDY].

'See United Nations Association, United States Foreign Policy and Human Rights 68 (1979); CRS, SECURITY ASSISTANCE STUDY, supra note 5, at 6.

${ }^{7}$ See Newsom, Out Arsenal Must Include Our Values, Wash. Star, April 2, 1981, at A13, cols. 2-3; Whitaker, Rights and Realpolttik, N.Y. Times, Feb. 24, 1981, at A19, col. 4; Cohen, Wrong on Human Rights, NEw RePUBLIC, March 28, 1981, at 13-14.

${ }^{8}$ See Syrkin, Can a Human Rights Pollcy Be Consistent?, in Human Rights and U.S. Foreign Policy 200, 202, 212 (P. Brown \& D. MacLean eds. 1979).

${ }^{9} 22$ U.S.C. $\$ 2304$ (Supp. III 1979). $\quad{ }^{10} \mathrm{Id}$. subsection (a)(2).
} 
arms sales] and . . . on all the facts it is in the national interest of the United States [to continue such assistance]."11

The history of the enactment and implementation of section 502B illuminates the obstacles encountered when Congress tries to influence executive decisions on foreign policy. It is not simply a question of enacting legislation that the Executive implements as a matter of course. A hostile administration may avoid implementation, as during the Nixon and Ford years. ${ }^{12}$ Even if high political officials seem sympathetic (as they did during the Carter administration), entrenched bureaucratic interests may actively resist the law, particularly where its subject is human rights and foreign policy. The history also contributes to understanding foreign policy decisions as the product of conflict among bureaucracies with competing interests. ${ }^{13}$ The implementation of section 502B

${ }^{11} I d$. subsection (c)(1)(C).

Section 502B contains, in addition to the basic rule, a number of other provisions:

1. Subsection (a)(1) states that "a principal goal of the foreign policy of the United States shall be to promote the increased observance of internationally recognized hurnan rights by all countries."

2. Subsection (a)(2) also prohibits the sale of certain equipment to the police of a government engaged "in a consistent pattern of gross violations of internationally recognized human rights."

3. Subsection (a)(3) directs the President to formulate and conduct prograras of military aid and arms sales in a way that "will promote and advance human rights and avoid identification of the United States . . . with governments which deny to their people internationally recognized human rights."

4. Subsection (b) requires the Secretary of State to submit to Congress each year a report on human rights conditions in each country to which the United States proposes to give military aid or sell arms.

5. Subsection (c) establishes a specific procedure by which Congress may reverse an executive decision to provide military aid or sell arms to a particular government.

6. Both subsections (b) and (c) state that, in implementing section 502B, the Secretary of State is to consult with a designated Department of State official, the Assistant Secretary for Human Rights.

7. Subsection (d) defines a number of terms, including the phrase "internationally recognized human rights."

8. Subsection (e) provides that the President may furnish security assistance "to any country with respect to which the President finds that such a significant improvement in its human rights record has occurred as to warrant lifting the prohibition on furnishing such assistance in the national interest of the United States."

9. Subsection ( $f$ ) requires the President in allocating funds under chapter 22 or the Arms Export Control Act to "take into account significant improvements in the human rights record of recipient countries."

${ }^{12}$ For the best available account of the role of human rights in the forcign policies of the Nixon, Ford, and Carter administrations, see R. Cohen, Human Rights Decision-Making in the Executive Branch: Some Proposals for a Coordinated Strategy, in HUMAN RIGHTS AND AMERICAN FOREIGN Policy 212 (D. Kommers \& G. Loescher eds. 1979) [hereinafter cited as R. Colıen, Human Rights].

${ }^{13}$ For the two seminal works in this area, see G. Allison, Essence of Decision (1971); M. Halperin, Bureaucratic Politics and Foreign Policy (1974). In explaining frolicymaking in the bureaucratic process, Allison argues that "what happens is not chosen as a solution to a problem but rather results from compromise, conflict, and confusion of officials with diverse interests and unequal influence." G. Allison, supra, at 162. 
during the Carter years is a story of bureaucratic warfare of the most intense sort. The principal antagonists were the career Foreign Service, with responsibility for the day-to-day management of relations with other countries, and a newly created Department of State Bureau of Human Rights, staffed to a great degree by outsiders. Largely because of the career bureaucracy's resistance to implementation, the Carter record may surprise some readers and also appear to contradict the former President's aggressive public embrace of a human rights oriented foreign policy. It is true that his administration went much further in implementing the statute than its predecessors (who simply disregarded section 502B). But it was considerably more cautious and tentative than may be generally supposed and, at some points, may itself have violated the law.

The article is divided into four parts. Part I discusses the evolution of section $502 \mathrm{~B}$ and disregard of the statute by the Nixon and Ford administrations. Part II examines the career bureaucracy's resistance to implementation during the Carter administration. Part III analyzes decisions reached during the Carter years, explaining how the statute was interpreted to reduce military aid and arms sales to specific countries. ${ }^{14}$ Part IV discusses implications of this study for congressional attempts to influence the Executive's conduct of foreign policy and suggests avenues for further research.

\section{The Evolution of Section 502B}

Congress enacted legislation on the subject of human rights and military ties for the first time in 1973. From the beginning, the legislation was openly disregarded by the Nixon and Ford administrations, primarily owing to the opposition of Secretary of State Henry Kissinger. ${ }^{15}$ Congress responded by

\footnotetext{
${ }^{14}$ In recounting the implementation of section 502B, this report draws in part on the experience of the author in the Department of State during the Carter administration as one of those responsible for enforcement of section 502B. Although every effort has been made to check his recollections with those of others, the history inevitably reflects his own views and bias. It would not be possible to write on this subject without relying to a significant degree on the personal accounts of those who served in the executive branch. Information that indicates how section 502B was applied to specific questions is, in general, not available to the public. The decisions were made in private within the Department of State, they were rarely publicized by the executive branch, and only on occasion did Congress use its oversight role to elicit detailed explanations of them. The internal Government documents that do furnish a written record will not be publicly available for a number of years, and at any rate, this record is incomplete and to some extent misleading. Some decisions were never recorded at all and the record of others was designed, not to describe accurately the decisions or how they were made, but to place them in the best possible light.
}

Allison provides a good account of the problem:

Information about the details of differences in perceptions and priorities within a government on a particular issue is rarely available. Accurate accounts of the bargaining that yielded a resolution of the issue are rarer still. Documents do not capture this kind of information. What the documents do preserve tends to obscure, as much as enlighten. . . . As a master of this style of analysis has stated, "If I were forced to choose between the documents on the one hand, and late, limited, partial interviews with some of the principal participants on the other, I would be forced to discard the documents."

Allison, supra note 13, at 181 (quoting Richard Neustadt).

${ }^{15}$ R. Cohen, Human Rights, supra note 12, at 220-21; T. FrancK \& E. WEISBaNd, Foreign Policy by Congress 85 (1979); Congressional Research Service, Human Rights and U.S. Foreign assistance: Prepared for the Senate Comm. on Foreign Relations, 96th Cong., 1st Sess. 84-85 (Comm. Print 1979) [hereinafter cited as CRS, HuMAN Rights STUDY]. 
regularly expanding and amending its initial product in an attempt to tighten the law and thus ensure that human rights concerns would be taken into account in executive branch decisions. During Kissinger's tenure, however, Congress was almost entirely unsuccessful in influencing the Executive to change its behavior. Kissinger's persistent noncompliance with the law was foreshadowed during his confirmation hearings when he explicitly rejected the inclusion of human rights objectives in American foreign policy: "But I do believe that it is dangerous for us to make the domestic policy of countries arourd the world a direct objective of American foreign policy. . . ."16

The absence of discernible impact resulted not only from the Executive's opposition to conditioning military aid and arms sales on human rights factors, but also from the fact that for this entire period the legislation wias in a form that made it advisory. The statute became a binding legal requirement only in 1978, when Congress decided that earlier versions had not had a sufficient impact. The following discussion reviews the legislative history thar culminated in the 1978 amendments, which left the statute essentially as it is today.

\section{The General Rule}

Section 502B was not the first attempt by Congress to legislate on human rights and military relationships. It was preceded by section 32 of the Foreign Assistance Act of 1973, enacted on December 13 of that year. ${ }^{17}$ This provision was couched in "sense of the Congress" language. So cast, it expressed a legislative viewpoint that was not legally binding, a form chosen to allow the Executive flexibility in implementation. Section 32 stated: "It is the sense of Congress that the President should deny any . . . military assistance to the government of any foreign country which practices the internment or imprisonment of that country's citizens for political purposes." 18

In June 1974, 6 months after the enactment of section 32, Robert \$. Ingersoll, Assistant Secretary of State for East Asian and Pacific Affairs, testified before the House Foreign Affairs Committee that the Nixon administration had taken no steps to act on the sense of Congress expressed in section $32 .{ }^{19} \mathrm{~A}$ few weeks later, Ingersoll submitted a detailed explanation in which he argued that it was too difficult to define "political prisoner" objectively, expressed doulst that cutting aid was ever an effective or appropriate foreign policy response to human rights violations, and singled out private diplomacy as the preferred means for pursuing human rights concerns. ${ }^{20}$

At about the same time that section 32 was first proposed, Representative Donald Fraser began a parallel effort, which eventually led to enactment of

\footnotetext{
${ }^{16}$ Nomination of Henry A. Kissinger: Hearings Before the Senate Comm. on Forelgn Relations, 93d Cong., 1st Sess. 117 (1973).

${ }^{17}$ Foreign Assistance Act of 1973, $\$ 32,87$ Stat. 733 (1973).

18 Ibid.

${ }^{19}$ Fiscal Year 1975 Foreign Assistance Request: Hearings Before the House Comm. on Foreign Affairs, 93d Cong., 2d Sess. 280-81 (1974).

${ }^{20}$ Letter from Robert S. Ingersoll to the Honorable Thomas E. Morgan (June 27, 1974), reprinted in id. at $284-86$.
} 
section 502B. During the fall of 1973, the House Subcommittee on International Organizations and Movements, under Fraser's leadership, began a series of extensive hearings on the subject of human rights and foreign policy ${ }^{21}$ and, in early 1974, issued a 54-page report emphasizing the existence of a body of international law that recognizes certain basic rights owed by all governments to their citizens. ${ }^{22}$ The report further stated that the United States was obligated not only to respect these rights within its own jurisdiction, but also to avoid supporting other governments engaged in violating them. ${ }^{23}$ The report concluded, however, that the United States had failed to meet its obligations:

The human rights factor is not accorded the high priority it deserves in our country's foreign policy. Unfortunately, the prevailing attitude has led the United States into embracing governments which practice torture and unabashedly violate almost every human rights guarantee pronounced by the world community. . . . [C]onsideration for human rights in foreign policy is both morally imperative and practically necessary.. . . The State Department too often has taken the position that human rights is a domestic matter and not a relevant factor in determining bilateral relations. When charges of serious violations of human rights do occur, the most that the Department is likely to do is make private inquiries and low-keyed appeals to the government concerned. ${ }^{24}$

The report made numerous recommendations for change in the conduct of U.S. foreign policy, among which was the idea that military ties should be affected by human rights concerns: "The Department of State should discourage governments which are committing serious violations of human rights through various measures such as . . . withdrawal of military assistance and sales."25

In an effort to goad the Executive into taking account of human rights, Fraser proposed and Congress enacted the initial version of section 502B in December $1974 .^{26}$ In its first incarnation, section 502B, like section 32, expressed the "sense of Congress" and was therefore merely advisory, rather than binding. It stated:

It is the sense of the Congress that, except in extraordinary circumstances, the President shall substantially reduce or terminate security assistance to any government which engages in a consistent pattern of gross violations of internationally recognized human rights, including torture or cruel, inhuman, or degrading treatment or punishment; prolonged detention without charges; or other flagrant denials of the right to life, liberty, and the security of the person. ${ }^{27}$

${ }^{21}$ See generally Intemational Protection of Human Rights, The Work of International Organizations and the Role of U.S. Foretgn Policy: Hearings Before the Subcomm. on International Organzzattons and Movements of the House Comm. on Foreign Affairs, 93d Cong., 1st Sess. (1974).

22 See generally SUbCOMM. ON INTERNational ORGanizations AND MOVEMENTS OF the House Comm. on Foreign Affairs, HuMan Rights in the World CoMAunity: A Call FOR U.S. LeADership, 93d Cong., 2d Sess., at 9-11 (Comm. Print 1974) [hereinafter cited as FRASER REPORT].

${ }^{23}$ See generally FRASER REPORT, supra note 22, at 17-45.

24 Id. at $9-10$.

$25 \mathrm{Id}$. at 11 .

${ }^{26}$ Foreign Assistance Act of $1974, \$ 46,88$ Stat. 1815 (1974) (current version at 22 U.S.C. $\$ 2304$ (Supp. III 1979)).

${ }^{7}$ Ibid. 
The substantive standard of section 502B differed from that of section 32 in three important respects. First, the statute used the term "security assistance" (rather than "military assistance"), and this new term was defined to include sales of arms for cash as well as military aid. ${ }^{28}$ Second, it changed the category of relevant human rights violations from "internment or imprisonment" for "political purposes" to "torture," "prolonged detention without charges," and other inhuman treatment. ${ }^{29}$ By replacing a status that lacked a precise definition with specific practices, Congress appears to have been responding directly to Ingersoll's complaint that the violations under section 32 had been too difficult to define objectively. Third, it attempted to recognize the need for executive flexibility by providing an "extraordinary circumstances" exception (but at the same time required the President to report to Congress when exceptions were to be made).

It soon became apparent, however, that the Executive, just as it had ignored section 32, intended to give absolutely no effect to the sense of the Congress as expressed in section 502B. In November 1975, the Under Secretary of State for Security Assistance, Carlyle E. Maw, testified that in no case during the preceding year had military aid or arms sales been denied on human rights grounds. ${ }^{30}$ At the same time, the administration submitted to Congress a report on executive compliance with section 502B. Instead of providing the information required by the statute, the report attacked the policy enunciated by section 502B and clearly implied that the Executive had no intention of ever refusing military aid or arms sales to any government on human rights grounds. ${ }^{31}$

One month later, frustrated by the blatant refusal of the Executive to implement section $502 \mathrm{~B}$, Congress attempted to transform the statute from a statement of its own sentiments into a mandatory requirement. ${ }^{32}$ In response to a proposal by Representative Fraser, Congress voted to delete the "sense of the Congress" language and make section 502B legally binding. ${ }^{33}$ The House report on the bill emphasized the need to strengthen the statute in order to enforce the will of the Congress:

Unfortunately, the executive branch response to the existing human rights provision has not been satisfactory. . . . In fact, increased levels of

\footnotetext{
${ }^{28}$ Under the 1974 version of the statute, security assistance was defined to include "assistance under chapter 2 (military assistance) . . . [and] sales under the Foreign Military Sales Act." Foreign Assistance Act of 1974, $\$ 46,88$ Stat. 1816 (1974) (currently codified at 22 U.S.C. $\S 2304(d)(2)$ (Supp. III 1979)).

${ }^{29}$ Id. $\$ 46,88$ Stat. 1815 (currently codified at 22 U.S.C. \$2304(a)(1) (Supp. III 1979)).

${ }^{30}$ International Securily Assistance Act of 1976: Hearings of the House Comm. on International Relations, 94th Cong., 1st \& 2d Sess. 207-08 (1976) [hereinafter cited as 1976 Act Hearings].

31 U.S. DEP'T OF STATE, REPORT TO THE CONGRESS ON THE HUMAN RIGHTS IITUATION IN Countries Receiving U.S. Security Assistance (1975), reprinted in Foreign Assistance Authorization Arms Sales Issues: Hearings Before the Subcomm. on Foreign Assistance of the Scnate Comm. on Foreign Relations, 94th Cong., 1st Sess. 377 (1976). Representative Fruser is quoted as having found "the report to be primarily a defense of the State Department's apparent intention not to comply with the law." Gwertzman, U.S. Blocks Human Rights Data, on Netions Getting Arms, N.Y. Times, Nov. 19, 1975, at 1, col. 1, 14, col. 4.

${ }^{32}$ See 1976 Act Hearings, supra note 30 , at 498-500.

33122 CONG. REC. 9587-88 (1976).
} 
security assistance were requested for a number of countries where serious human rights problems exist.

Consequently, the committee approved the above amendment to Section 502B which makes it binding that the President include human rights considerations in the process in determining levels and kinds of assistance for recipient countries. ${ }^{34}$

President Ford vetoed the foreign aid authorization bill that contained these changes on May 7, 1976. In his veto message, he objected to the transformation of section $502 \mathrm{~B}$ into a binding directive. ${ }^{35}$ Two months later, after a compromise was reached, President Ford signed a revised bill. The sense of the Congress language was replaced by an introduction stating that the section $502 \mathrm{~B}$ standard was "the policy of the United States."36 Although the language was weaker than a binding legal requirement, the Senate report indicated that Congress expected the policy to be implemented: "The Committee has taken action in this bill to ensure that numan rights considerations are brought to bear on decisions made within the Executive Branch . . . relating to the provision of ... security assistance."37

In January 1977, the Carter administration entered office. Every year for the preceding 4 years, the issue of how human rights concerns should affect military ties had been the subject of congressional action. This time Congress refrained from attempting to strengthen the basic substantive rule of section $502 \mathrm{~B}(\mathrm{a})(2)$ in order to allow the new Carter administration, publicly committed to renewed emphasis on human rights in foreign policy, an opportunity to implement the legislation as it existed. However, Congress did underline its continuing concern about military ties to repressive governments by providing for the creation of the position of Assistant Secretary of State for Human Rights, with responsibility for participating in decisions on security assistance. ${ }^{38}$ In

\footnotetext{
${ }^{34}$ H. R. REP. No. 94-848, 94th Cong., 2d Sess. 15 (1976).

${ }^{35}$ President's Message to the Senate Returning S. 2662 Without His Approval, 12 WEEKLY COMP OF Pres. DOC. 826, 828 (May 7, 1976).

${ }^{36}$ International Security Assistance and Arms Export Act of 1976, $\$ 301,90$ Stat. 748 (1976) (current version at 22 U.S.C. $\$ 2304$ (Supp. III 1979)).

${ }^{37}$ S. REP. No. 94-876, 94th Cong., 2d Sess. 14-15 (1976).

${ }^{38}$ Foreign Relations Authorization Act, Fiscal Year 1978, \$109, 91 Stat. 846 (1977) (current version at 22 U.S.C. $\$ 2384$ (Supp. III 1979)). The statute provides in part:
}

(f)(1) There shall be in the Department of State an Assistant Secretary for Human Rights and Humanitarian Affairs who shall be responsible to the Secretary of State for matters pertaining to human rights . . . in the conduct of foreign policy. The Secretary of State shall carry out his responsibility under section 502B . . . through the Assistant Secretary.

(f)(2) The Assistant Secretary of State for Human Rights and Humanitarian Affairs shall maintain continuous observation and review of all matters pertaining to human rights . . . in the conduct of foreign policy, including-

(c) making recommendations to the Secretary of State . . regarding compliance with ... section [502B].

22 U.S.C. $\$ 2384$ (f)(1)-(f)(2) (Supp. III 1979). In its report on this legislation, the Senate Foreign Relations Committee explained the rationale for revising the statute:

Human rights issues . . have clearly acquired an increased importance in the conduct of 
addition, members of the House International Relations Committee indicated that they would watch closely actions taken by the new administration to implement section 502B. ${ }^{39}$

One indication of congressional opinion that the first year of Carter efforts, although substantial, did not go far enough is that in 1978 Congress resumed the process of strengthening section $502 \mathrm{~B}$ by deleting the prefatory "it is the policy of the United States" language from subsection (a)(2). As a result, it directly states that, absent "extraordinary circumstances," "no sccurity assistance may be provided to any country, the government of which engages in a consistent pattern of gross violations of internationally recognized human rights." 40 The Conference Committee report made it clear that, a.s a result of the deletion, section $502 \mathrm{~B}(\mathrm{a})(2)$ was to be a binding requirement that the Executive was obligated to follow as a matter of law:

[T] he intended effect of this amendment is to substitute for the current policy statement a legal requirement to deny security assistance. . . . [I]t is the intent of the committee of conference to place renewed emphasis on human rights as a major factor that must, as a matter of law, be taken into account in making security assistance decisions. ${ }^{41}$

\section{Country-Specific Legislation}

In 1974, when Congress originally enacted section 502B, it also began to pass legislation to limit military aid and arms sales to designated countries. The country-specific legislation was contained in bills authorizing or appropriating funds for military aid, and it named, at various times, Argentina, Brazil, Chile, El Salvador, Guatemala, Paraguay, the Philippines, South Korea, Uruguay, and Zaire. ${ }^{42}$ The legislation usually mentioned only military aid and was effective for a single year, although in two cases it expressly prohibited arms sales as well and was of indefinite duration.

Congress has successfully attached country-specific legislation to bills authorizing or appropriating military aid for every fiscal year since $1975 .{ }^{43}$ For

U.S. foreign policy, and this provision will serve to give additional stature to the State Department official charged with primary responsibilities in this area. The comrnittee would expect this new Assistant Secretary to be supported by such Deputy Assistant Serretaries and staff as are commensurate with the rank of Assistant Secretary.

S. REP. NO. 95-194, 95th Cong., 1st Sess. 16 (1977), reprinted in [1977] U.S. CDDE CoNG. \& AD. NEWS 1625, 1638.

${ }^{39}$ See Foreign Assistance Legislation for Fiscal Year 1978 (Part 1): Hearings Before the House Comm. on International Relations, 95th Cong., 1st Sess. 27 (1977) (remarks of Rep. Fraser) (committee expects that, if it refrains from intervening, new administration will not lapse into business-as-usual approach of predecessors); id. at 29 (remarks of Rep. Harrington) (administration must support rhetoric with action).

${ }^{40} 22$ U.S.C $\$ 2304(a)(2)$ (Supp. III 1979).

${ }^{41}$ H. R. ReP. No. 95-1546, 95th Cong., 2d Sess. 27 (1978), reprinted in [1978] U.S. CoDE CoNG. \& AD. NEws 1868, 1874.

${ }^{42}$ On some occasions, Congress has passed amendments that name specific countries. When the amendment does not name targeted countries, Congress reduces the overall aid reque 3 by a specific dollar amount and explains in committee reports how the cut is to be applied to specific countrics.

${ }^{43}$ In 1976 Congress amended section 502B to establish yet another method for it to reverse executive decisions to "provide security assistance" to a specific country. Under section 502B(c)(1), Congress initiates the reversal by requesting a report from the Secretary of State that indicates the 
example, Chile was prohibited from receiving any military aid in fiscal $1975^{44}$ and the amount requested for South Korea was substantially reduced. ${ }^{45}$ The legislation for fiscal 1976 contained an indefinite embargo on both military aid and arms sales to Chile. ${ }^{46}$ For fiscal 1977 , military aid to Uruguay was banned. ${ }^{47}$ For fiscal 1978, proposed military aid was eliminated for Argentina, Brazil, El Salvador, Guatemala, ${ }^{48}$ Nicaragua, Paraguay, ${ }^{49}$ and Uruguay, ${ }^{50}$ and reduced for the Philippines. ${ }^{51}$ Beginning in fiscal 1979, an indefinite ban was

country's human rights practices and whether extraordinary circumstances require a continuation of security assistance to it. Section $502 \mathrm{~B}(\mathrm{c})(4)(\mathrm{A})$ provides that after receiving the report, "Congress may adopt a joint resolution terminating . . . [or] restricting security assistance for a country."

Curiously, this additional procedure is so cumbersome and ineffective that it has been initiated only rarely and never has it been carried beyond the opening steps. Not once during Carter's term did Congress use section $502 \mathrm{~B}(\mathrm{c})$ ta challenge an executive decision. The procedures were invoked only in 1976 during the last year of the Ford administration. At that time, the House Foreign Affairs Committee requested reports for six countries (Argentina, Haiti, Peru, Iran, Indonesia, and the Philippines), but took no additional steps once the reports were received. Thus, no joint resolution to terminate security assistance has ever been proposed or voted on under section 502B(c)(4), See U.S. DeP'T of State, Human Rights and U.S. Policy: Argentina, Haiti, Indonesia, Iran, Peru, and the Philippines, Reports Submitted to the House Comm. on International Relations, 94th Cong., 2d Sess. (Comm. Print 1976) (setting forth congressional requests and State Department's responses).

14 Foreign Assistance Act of 1974, $\$ 25,88$ Stat. 1802 (1974).

${ }^{45}$ Congress provided that South Korea could receive only $\$ 145$ million in military aid in fiscal year 1975 unless the President provided a report to Congress "stating that the government of South Korea is making substantial progress in the observance of internationally recognized standards of human rights." Id. $\$ 26(\mathrm{a})$. If the President submitted the report, South Korea could receive an additional $\$ 20$ million in military aid. Id. $\$ 26(b)$.

${ }^{46}$ International Security Assistance and Arms Export Control Act of 1976, §406, 90 Stat. 758 (1976). At the end of 1981, the embargo was replaced with a directive that no security assistance be provided to Chile unless the President first certifies, inter alia, that the Government has made "significant progress in complying with international human rights." International Security Development Cooperation Act of 1981, Pub. L. No. 97-113, \$726. A similar provision was enacted for Argentina. Id., $\$ 725$.

${ }^{17}$ Pub. L. No. 94-441, 90 Stat. 1473 (1976).

${ }^{48}$ Under the appropriations bill for military aid for fiscal year 1978, Congress prohibited the Executive from providing military sales credits to Argentina, Brazil, El Salvador, Guatemala, and Uruguay. Pub. L. No. 95-148, \$503, 91 Stat. 1239 (1977).

${ }^{49}$ Under the International Security Assistance Act of 1978, Congress also eliminated military training assistance to Paraguay and Nicaragua, but in doing so it did not name them specifically in the legislation. The conference report explained:

The Committee of conference agreed (1) to avoid naming specific countries in the statute, and (2) to cut the international military and education training account by $\$ 300,000$ - the exact amount which had been programmed for both Nicaragua and Paraguay.

The elimination of references to specific countries should not be interpreted as approval of the human rights practices in either Nicaragua or Paraguay. This bill already contains a clear and concise prohibition on grant military training to any country which engages in a consistent pattern of gross violations of internationally recognized human rights.

H. R. REP. No. 95-1546, supra note 41, at 31, [1978] U.S. CoDE CoNG. \& AD. NEws at 1878. ${ }^{50}$ See note 48 supra.

51 Under the appropriations bill for security assistance for fiscal year 1978, Congress appropriated $\$ 18.1$ million in military aid grants, $\$ 1.85$ million in military sales credits, and $\$ 700,000$ in military training funds for the Philippines. Pub. L. No. 95-148, supra note 48 , \$503C. The administration had requested $\$ 20$ million in military sales credits and $\$ 800,000$ in military training funds. U.S. 
placed on both military aid and arms sales to Argentina. ${ }^{52}$ In budgets for fiscal 1980 and 1981 , Congress reduced military aid for Zaire. ${ }^{53}$ The liggislation for fiscal 1981 also eliminated it for Guatemala. ${ }^{54}$

Although usually applicable only to military aid and of limited duration, the country-specific legislation was also a finding by Congress that the Executive had failed to apply section 502B to a government engaged in "gross violations" and that "extraordinary circumstances" would not justify past levels of military aid. The repeated willingness of Congress to legislate on specific countries placed the Executive on notice: unless it began to apply section 502B, Congress might legislate again. While this prospect did not move the Ford and Nixon administrations to alter their practice, it appears to have had significant influence on the Carter administration.

\section{Resistance of the Career Bureaucracy Under Carter}

The installation of the Carter administration in January 1977 produced a dramatic shift in attitudes of high political officials on the human rights issue. ${ }^{55}$ As a presidential candidate, Jimmy Garter had strongly advocated increased emphasis on human rights in American foreign policy and he reaffirmed this position in his inaugural address. ${ }^{56}$ Although he did not mention the specific issue of human rights and military ties or indicate his position on implementation of section 502B, his personal call for a human rights oriented foreign policy implied a promise to do considerably more than his predecessors to follow the legislation.

The executive branch, however, did not attempt to conform to the statute's requirements without a fierce internal struggle. Despite the change in attitudes at the highest political level (from opposition to section 502B to tindorsement of its underlying principle), the Department of State's career bur(aucracy remained implacably hostile and continued to resist implementation. The result was intense bureaucratic warfare between career officials, who resisted implementation, and the office of the newly established Assistant Secretary for Human Rights, which sought adherence to the law.

Dept of State, Congressional Presentation For Security Assistance Program FY 1978, at 4 (1977).

52 International Security Assistance Act of 1977, §11, 91 Stat. 619-20 (1977), cis amended by International Security Assistance Act of 1978, $\$ 12(c)(1), 92$ Stat. 737 (1978). The embargo was repealed at the end of 1981 . See note 46 supra.

${ }^{53}$ Under the International Security Assistance Act of 1979, which provided the security assistance authorization levels for fiscal year 1980, Congress reduced the funds available to Zaire for military sales credit guarantees to $\$ 8$ million from the $\$ 10$ million requested by the administration. $H$. $R$. REP. No. 96-495, 96th Cong., 1st Sess. 21 (1979), reprinled in [1979] U.S. CODE CONG. \& AD. News 1682, 1688. Under the International Security and Development Cooperation Act of 1980, which established the authorization levels for security assistance for fiscal year 1'81, Congress further reduced to $\$ 6$ million the military sales guarantees for Zaire. See H. R. REP. NO. 961471, 96th Cong., 2d Sess. 42 (1980), reprinted in [1980] U.S. CODE CONG. \& AD. NEwS 10,881, 10,886 .

${ }^{54}$ Morgan, Panel Rebuffs U.S. Bid To Relax a Rights Sanction, Wash. Post, March 23, 1979, at $\mathrm{A} 2$, col. 3 .

${ }^{55}$ See Drew, A Reporter at Large: Human Rights, NEW YORKER, July 18, 1977, at 36.

${ }^{56}$ Inaugural Address of President Jimmy Carter, 13 WeEkLY COMP. OF PREs. DOC. 87, 88 (Jan. 24, 1977). 


\section{The Attitude of the Career Bureaucracy}

The career bureaucracy of the Department of State is the Foreign Service, and the core of the Foreign Service serves in the five regional bureaus for Africa, East Asia, Europe, Latin America, and the Near East. Each bureau has responsibility for managing relations with countries within its region, including issues of military aid and arms sales.

The opposition of the Foreign Service to section 502B was a logical consequence of its conception of its special role or of (what one student of the bureaucracy has labeled) its "organizational essence." 57 The Foreign Service views its primary role or essence as the maintenance of smooth and cordial relations with other governments. ${ }^{58}$ It believes that military aid and arms sales are an indispensable means to achieving this goal. When provided, the other government is grateful and more inclined to get along with the United States. When refused, a cordial relationship may be harder to maintain, especially if the other government suspects that the reason for refusal is a judgment that it has mistreated its own citizens.

Keeping other governments happy becomes an end in itself. This phenomenon is often referred to as "clientism" because the Foreign Service views other governments as "clients" with whose interests it identifies, rather than as parties to be dealt with at arm's length according to the national interest of the United States. ${ }^{59}$

The regional bureaus generally make recommendations without rigorously analyzing whether providing security assistance to a particular government will, in fact, serve concrete foreign policy objectives of the United States. Nor is there consideration of whether alternative means might accomplish what is desired. There is rarely exploration of whether the United States might supply economic aid or count on mutual interests to achieve diplomatic goals.

Furthermore, costs are typically excluded from the calculation. The time horizon of the career bureaucracy is short and the possible long-run disadvantage of aiding repressive governments seems alien to its thinking. Even after the examples of Iran and Nicaragua, there is rarely consideration that a particular regime may be overthrown and United States support for it resented by those who follow. Nor is the damage to U.S. standing in the world, or the

${ }^{57}$ See generally M. HALPERIN, supra note 13, at 28-40.

${ }^{58}$ See generally Silberman, Toward Presidential Control of the State Department, ForEIGN AfFalRS, Spring 1979, at 872; Krizay, Clentitus, Corpulence, and Cloning at State: The Symptomatology of a Stck Department, POLICY REV., Spring 1978, at 39. Krizay states: "'Good relations' or 'warm relations' are often thought of as an objective to be protected from the threat of domestic interest rather than as an instrument for furthering them." Krizay, supra, at 42.

${ }^{59}$ See Silberman, supra note 58 , at 882 . Silberman states:

Inevitably . . . a Foreign Service officer has a tendency toward what is referred to in the State Department as "clientism," a term which suggests overemphasizing the interests of a foreign country (as defined by the governing elite) vis-a-vis the broader interests of the United States. "Good relations" between the host country and the United States (often at our expense) become an end in themselves without sufficient regard to U.S. geopolitical and geostrategic interests.

Ibzd. Another author prefers the term "clientitus." See Krizay, supra note 58, at 43. In Krizay's view, "[c]lientitus is widely recognized as one of the State Department's most unfortunate characteristics. Simply defined, it refers to a tendency to look upon the country or countries within an office's geographic responsibilities as 'clients' deserving special attention." Ibid. 
conflict with both international legal obligations and traditional American values, weighed in the balance. In effect, the career bureaucracy develops its position by reckoning the national interest in terms of pleasing its "clients," the governments with which it conducts diplomatic relations. ${ }^{60}$

The phenomenon of "clientism" has a number of causes. A Foreign Service officer is typically required to develop personal relations and spend substantial periods of time with high officials of other governments. He tends, therefore, to sympathize and identify with their point of view. ${ }^{61}$ If the other government is accused of human rights abuses, he deals with officials who either deny the accusations or explain the excesses as regrettable, but necessary to stem "terrorism" and avoid social chaos. He is much less likely to encounter the victims of repression and hear their point of view.

In addition, the tour of duty in the Foreign Service is usually of 2 to 3 years' duration, after which the officer is rotated to another post. An officer is likely to work on country $A$ for 3 years, then switch to country $B$, then to country $C$, and so on. Thus, the short duration reduces the incentive to consider the longer run consequences of decisions.

Moreover, the penalty for questioning established values is heavy. ${ }^{62}$ According to one recent Deputy Under Secretary of State:

Under the present system, the key factor in determining whether an officer will be promoted is the efficiency report written by his immediate supervisor. The knowledge that the good opinion of his supervisor is crucial in determining whether an officer advances at a normal rate or falls behind and is eventually selected out can act as a powerful deterrent to his forthright expression of views on policy matters which may be at variance with views of his supervisor. ${ }^{63}$

Since 1973, when Congress first enacted section 32, the regicnal bureaus have continually opposed implementation of legislation conditioring security assistance on human rights concerns. They have virtually never initiated a proposal that military aid or arms sales be cut off or reduced on account of a government's human rights performance. Even after the Carter administration

${ }^{60}$ See M. HaLPERIN, supra note 13, at 62. In Halperin's view, "[c]areer officials . . . often develop their position largely by calculating the national interest in terms of organizitional interests of the career service to which they belong." Ibid.

${ }^{61}$ See Silberman, supra note 58, at 883. Silberman states: "The other kind of risk typically eschewed by career officers is too vigorous a defense of American interests because such behavior can lead to relative unpopularity with the nation or group of nations in which the officer specializes. .." Ibid.

62 See M. HALPERIN, supra note 13, at 85-86. Halperin states: "The desire for promotion will lead a career official to support the interests of the organization of which he is a member, since he recognizes that promotion will, in large measure, depend on the individual being seen as advancing the interest of his organization." Ibid.

${ }^{63} \mathrm{~W}$. MACOMBER, DIPLOMACY FOR THE 1970'S: A PROGRAM OF MANAGEMEN'C REFORM FOR THE DEPARTMENT OF STATE 21-22 (1970). Krizay makes the same point: "The annual Officer Evaluation Report, virtually to the exclusion of all else, determines the officer's career. As a consequence, each officer goes to great lengths to please his superior. . . . A kind of blind loyalty results, reinforcing and exacerbating all the evils of the Department's organization." Krizay, supra note 58 , at 49 . 
entered office in 1977, the regional bureaus vigorously fought nearly all attempts to apply section 502B to specific cases. This resistance took a number of different forms. First, they tried to minimize the relevance of section 502B. During the first 2 years, they argued that it could be ignored because it was merely a statement of policy and not legally binding. After it was made legally binding, they argued that the statutory rule was only one of several factors to be weighed in decisions on security assistance. ${ }^{64}$

Second, the career bureaucracy attempted to distort information about human rights conditions in particular countries. ${ }^{65}$ The extent of abusive practices was consistently underreported. For example, the Bureau for East Asia persisted in arguing that reports of Indonesian abuses in East Timor were grossly exaggerated and that few abuses had been committed by the Indonesian Army against the Timorese. In fact, an accumulation of reports from reputable sources indicates that a hundred thousand or more Timorese may have died at the hands of the Indonesian military. ${ }^{66}$ In the case of Argentina, the Latin American Bureau argued that, at most, hundreds of individuals had been summarily executed by security forces. As the evidence became incontrovertible that the number was actually 6,500 or more, the bureau shifted gears and argued that only Marxist terrorists were the victims. ${ }^{67}$ When it was documented that most of the victims were neither Marxists nor terrorists, the bureau maintained that the abuses were the work of local military commanders whom the ruling junta was struggling to control.

As it minimized or concealed negative aspects of a "client's" human rights practices, the career bureaucracy exaggerated positive signs. Improvements were said to have occurred on the basis of insubstantial evidence or self-serving declarations of the government in power. In 1978, for example, the Bureau for the Near East reported that the Shah of Iran was undertaking a major liberalization program, including an end to torture, release of all political pris-

\footnotetext{
${ }^{64}$ Halperin indicates that, in general, "when . . . legal requirements are not compelling, participants will obey the rules if they feel that the advantages of disobeying or ignoring the rules ... will in the long run be outweighed by the adverse consequences of having once ignored the rules." M. HALPERIN, supra note 13 , at 110 .

${ }^{65}$ In Halperin's view, "[c]oncern with organizational interests inclines participants to refuse to report or to concede facts. ..." Id. at 144. See also CRS, HUMAN RIGHTS STUDY, supra note 15 , at 92 .

${ }^{60}$ Kamm, The Stlent Suffering of East Timor, N.Y. Times, Feb. 15, 1981, §6, at 35; Kohen, Inzulation to a Massacre in East Timor, THE NATION, Feb. 7, 1981, at 136.

${ }^{67}$ In its 1979 human rights report, the State Department described attempts to estimate the number killed by Argentine security forces, often referred to as the "disappeared":

The most carefully recorded and documented list of unexplained disappearances, compiled by the Permanent Assembly for Human Rights in Buenos Aires, contains about 6,500 cases for the period 1976 to 1979. Some estimates, however, run considerably higher. The Mission of the New York City Bar Association . . . considers a figure of 10,000 as more accurate, while Amnesty International asserts that 15-20,000 persons have disappeared.
}

U.S. DeP'T OF STATE, Country Reports on HuMan Rights Practices For 1979, Report SUBMITTED TO THE SENATE COMM. ON FOREIGN RELATIONS AND THE HOUSE COMM. ON FOREIGN AFfalrs, 96th Cong., 2d Sess. 239 (Joint Comm. Print 1980). See generally Human Rights and the Phenomenon of Disappearances: Hearings Before the Subcomm. on International Organizations of the House Comm. on Foreign Affairs, 96th Cong., 1st Sess. (1979). 
oners, and transfer of political authority to an elected parliament. ${ }^{68}$ It predicted that this plan would be favorably received by broad segments of the Iranian population. ${ }^{69}$ It did not communicate, however, that credible reports of torture persisted, that the secret police continued to arrest political dissidents, that parliamentary elections were rigged and parliamentary powers evanescent, and that Iranians generally regarded the "liberalization" program as a sham. ${ }^{70}$ In 1979, the Bureau of African Affairs expressed similar optimism about a decision by Mobutu Sese Seko, President of Zaire, to permit formation of a legislative assembly. While the bureau admitted that the assembly lacked direct political authority, it was still touted as having unlimited powers to debate and question government policies. The bureau neglected to report that Mobutu threatened assembly members who tried to pry into sensitive subjects, such as official corruption, and effectively stopped their inquiries. ${ }^{71}$

Third, the regional bureaus overstated the extent of U.S. interests at stake in particular cases and the damage that could possibly result from failure to approve proposed security assistance. The Latin American Bureau, for example, insisted (albeit unsuccessfully) that failure to provide military aid to Paraguay would seriously undermine a relationship with the Stroessner Government that was important to fighting communism in Latin America. In another case, the Bureau for East Asia warned that, unless military aid to the Philippines was tripled, the United States might lose its military bases there. To support its contention, the bureau cited a threat by President Ferdinand Marcos to terminate an existing base agreement that still had 11 years to run. It failed to report, however, the opinion of a variety of experts that the threal. was empty and that Marcos would not risk breaking the legal obligation under an existing treaty. ${ }^{72}$

There were a few exceptions to the pattern of beliefs and behavior described above. Individual Foreign Service officers did attempt on occasion to challenge the wisdom of providing security assistance, although their chances of success were small and such questioning risked damaging their careers. ${ }^{73}$ Overall, the

${ }^{68}$ See S. Cohen, Who Lost Iran: Revising Revisionist History, Wash. Post, Sept. 20, 1980, at D2, cols. 3-4 [hereinafter cited as S. Cohen, Who Lost Iran].

${ }^{69}$ See ibid. $\quad{ }^{70} \mathrm{lbid}$.

${ }^{71}$ In 1981, the State Department's annual human rights report to Congress noted that the Zairian legislative assembly, which was "[q]uite active during 1979 and early $1980, \ldots$. . has since been reined in by the President." U.S. DEP'T OF STATE, CoUnTRY REPORTS ON HUMAN RIGHTS Practices: Report Submitted to the Senate Comm. on Foreign Relations and the House Comm. ON Foreign AfFairs, 97th Cong., 1st Sess. 310 (Joint Comm. Print 1981). Instead of merely reining in the assembly members, President Mobutu actually indicated to the members that if they continued to discuss forbidden subjects, he would silence them forever.

${ }^{72}$ As a representative of the Department of State, the author attended a conference of American Philippine scholars held at Eastern Michigan State University in May 1980. At that conference, he interviewed many of these scholars, all of whom expressed great surprise upon learning that some policymakers considered Marcos's threat credible.

${ }^{73}$ In one notable case, career officials in the Bureau for the Near East did question a plan to offer the Pakistani regime of Marshal Zia nearly a half-billion dollars in military aid. They were concerned about the extensive repression practiced by Zia and the resulting disaffection of large numbers of his people. Their sensitivity to the human rights factor had been heightened by the 
"clientist" impulse is thus quite strong and for the most part accurately describes the behavior of the career Foreign Service.

\section{The Human Rights Bureau}

Given the resistance of the career bureaucracy, concentrated in the regional bureaus, implementation of section 502B during the Carter administration depended on the newly created Bureau of Human Rights, headed by an outsider who was personally committed to the policy of the statute and staffed, to a significant degree, by persons from outside the career bureaucracy. The new bureau began to serve as a counterweight to the "clientism" of the regional bureaus. It took the initiative in insisting that section 502B had to be satisfied before security assistance could be provided, notwithstanding the argument of the career bureaucracy that the statute could be ignored or treated merely as one of several factors. The bureau also developed independent sources of information about human rights conditions in particular countries, which enabled it to challenge the factual reporting of the career bureaucracy ${ }^{74}$ Finally, it attempted to question the national security reasons offered to justify security assistance when the recipient appeared to "engage in gross [human rights] violations."

The creation of a special office for human rights within the Department of State was first recommended by Representative Fraser in $1974 .{ }^{75}$ Two years later, Congress created the post of Coordinator for Humanitarian Affairs, with overall responsibility for human rights matters in the Department. ${ }^{76}$ However, the Coordinator had a small staff, did not head a separate bureau, and was excluded from decisions on security assistance. ${ }^{77}$ In 1977 , shortly after Carter took office, Congress directed the designation of the Coordinator as an Assistant Secretary of State, with a specific list of legislated responsibilities, which served to effectuate the earlier Fraser recommendation of a separate bureau for human rights issues. ${ }^{78}$ The new Assistant Secretary for Human Rights was provided

\footnotetext{
fall of the Shah of Iran a few months earlier and the intense hostility of Iranians toward the United States for supporting the Shah. These officials did not want to support yet another highly unpopular regime, this time in Pakistan, and produce a repetition of the Iran fiasco. Notwithstanding these qualms, the Carter administration ultimately decided to provide Pakistan with $\$ 400$ million in economic and military assistance. Oberdorfer, Pakistan Offered \$400 Million Aid, Wash. Post, Jan. 15, 1980, at A1, col. 1. President Zia, however, dismissed this proposed assistance as "peanuts." Auerbach, Pakistan Seeking U.S. Guaranties in Formal Treaty, id., Jan. 18, 1980, at A1, col. 6 (quoting President Zia).

${ }^{74}$ Cf. CRS, HUMAN RIGHTS STUDY, supra note 15, at 66 (predisposition of many officials in some regional bureaus to downplay human rights violations has made it important for human rights office to develop its own sources of information).

${ }^{75}$ See FRASER REPORT, supra note 22, at 13. Additionally, Fraser recommended that a human rights officer be assigned to each regional bureau and that an Assistant Legal Adviser on Human Rights be appointed in the Legal Adviser's Office at the State Department. Ibid.

${ }^{76}$ International Security Assistance and Arms Export Control Act of 1976, $\$ 301(a)$, 90 Stat. 750 (1976) (current version at 22 U.S.C. $\$ 2384$ (Supp. III 1979)).

${ }^{77}$ R. Cohen, Human Rtghts, supra note 12 , at $219-20$.

${ }^{78}$ See note 38 supra (describing change in statute and rationale underlying it).
} 
with an enlarged staff and the office was officially recognized as a full-fledged bureau with a status comparable to that of the existing regional bureaus. ${ }^{79}$

This newly strengthened human rights office inserted itself into the established Department of State procedures with vigor. By virtue of section 502B, it was able to claim a right to participate in all decisions on security assistance. ${ }^{80}$ When it disagreed with the regional bureaus, which was quite frequent, it insisted that a decision paper-known formally as an action mernorandumbe prepared and sent to the Secretary of State for resolution of the issue.

During the first 18 months of the Carter administration, individual proposals for both military aid and arms sales were continually at issue between the regional bureaus and the Bureau of Human Rights and therefore "litigated" through the action memorandum procedure. ${ }^{81}$ In some ways, this resembled a judicial process, for it was adversarial in nature, and the action memorandum can be viewed as containing briefs for the position of each side. The action memorandum described each bureau's view of human rights conditions in the country concerned and of U.S. interests said to require approval of the proposed security assistance. The Human Rights Bureau argued its position in the context of section $502 \mathrm{~B}$. The bureau cited the statute and emphasized that there were two basic issues for decision: first, whether the proposed recipient was engaged in gross abuses, and second, whether extraordinary circumstances nevertheless required such assistance. The Human Rights Bureau challenged security assistance proposals when it believed the intended recipient was engaged in serious human rights abuses. The concerned regional bureau virtually always disagreed. The action memorandum process thus provided a formal mechanism by which the Human Rights Bureau could attempt to apply section 5012B to specific cases. ${ }^{82}$

\footnotetext{
79 During the Carter administration, the bureau, which began with a small staff, gradually expanded to about 20 persons, including 3 Deputy Assistant Secretaries and 12 human rights officers. Each human rights officer had primary responsibility for either a region, such as Africa, or a functional area, such as security assistance.

${ }^{80}$ Congress specifically acted to increase the stature of the head of the Human Rights Bureau. See S. REP. No. 95-194, supra note 38, at 16, [1977] U.S. CODE CONG. \& AD. NJEwS at 1638.

${ }^{81}$ Cf. CRS, HUMAN RIGHTS STUDY, supra note 15, at 2 (regional bureaus often argued against direct use of foreign assistance leverage but were generally opposed by Bureau of Human Rights).

${ }^{82}$ In its efforts, the Bureau of Human Rights was aided by the requirement of siction $502 \mathrm{~B}(\mathrm{~b})$ that the Secretary of State submit to Congress each year "a full and complete report . . . with respect to practices regarding the observance of and respect for internationally recognized human rights in each country proposed as a recipient of security assistance." 22 U.S.C. \$2304(b) (Supp. III 1979). In theory, the reports provide information concerning human rights practices in foreign countries, upon which Congress can evaluate the extent to which security assistance conforms with section $502 \mathrm{~B}(\mathrm{a})(2)$. In practice, however, members of Congress have access to infurmation from an array of outside sources on which they rely.

The more important function of the reports was that they forced the career bureaucracy to pay attention to human rights issues and thus mitigated, to a limited degree, its clientist tendencies. Foreign Service officers had to focus on human rights abuses that they might otherwi se have chosen to overlook. In the process of gathering information, they sometimes had to speak with political dissidents and victims of repression, which exposed them to other points of view and helped to counteract their tendency to associate only with high officials in power.
} 


\section{The Significance of Bureaucratic Resistance}

A recurring theme in modern studies of American government is the unresponsiveness of the bureaucracy to presidential decisions and directives. Presidents Roosevelt, Truman, Eisenhower, Kennedy, and Nixon all remarked on the persistent resistance of career bureaucrats to presidential policies they viewed as misguided. In his book, Bureaucratic Politics and Foreign Policy, Morton Halperin wrote:

[T] hose who are assigned to implement presidential decisions often do not feel obliged to execute their orders. Neither career officials nor political appointees necessarily feel that a presidential decision settles the matter. Participants still have different interests and still see different faces of an issue and have different stakes. They may believe that their conception of what is in the national interest is still correct, and they will resist efforts to do things which they feel are contrary to the national interest or to their own organizational or personal interest even if they have been directed by the President. ${ }^{83}$

The history of section 502B illustrates that the same basic point can be made about congressional directives. The opposition of the career Foreign Service to section 502B recalls comments made over a generation earlier by Franklin Roosevelt about his difficulties with the bureaucracy in general and the Department of State in particular:

The Treasury is so large and far-flung and ingrained in its practices that I found it impossible to get the action and results I want-even with Henry [Morgenthau] there. But the Treasury is not to be compared with the State Department. You should go through the experience of trying to get any changes in the thinking, policy, and action of the career diplomats, and then you'd know what the problem is. ${ }^{84}$

The bureaucracy is most likely to succeed in resisting legislation when high political officials are hostile to the congressional effort, as Kissinger was during the Nixon and Ford administrations. With the approval of its superiors, the bureaucracy can simply ignore the statute. Even when high political officials are sympathetic to the law, the career bureaucracy may resist implementation and the resistance may produce "political" compromises that only partially implement the law. The "political" compromises that arose during the Carter administration's implementation of section 502B are the subject of the next part of this report.

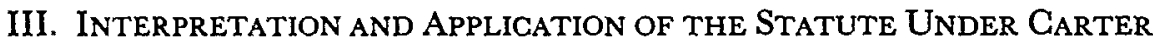

The public generally identifies the Carter administration with aggressive pursuit of a human rights oriented foreign policy. ${ }^{85}$ Some foreign affairs specialists have charged that its "single-minded" approach seriously overemphasized human rights objectives and failed to consider or pursue other im-

${ }^{33}$ M. HALPERIN, supra note 13 , at 245.

${ }^{84}$ M. ECCLES, BECKONING Frontiers 336 (1951).

${ }^{85}$ See generally Drew, supra note 55. 
portant foreign policy goals, to the detriment of U.S. interests. ${ }^{86}$ The general public's impression and the specialists' criticism are attributable, in large measure, to the rhetoric of high administration officials, particularly President Carter himself, who even 2 years into his term declared, "Human rights is the soul of our foreign policy." 87 Moreover, both perceptions suggest that the administration did considerably more than the minimum required by the standards of the law.

Yet a careful examination of actual decisions under section 5()2B leads to a very different conclusion: that the Carter administration exhibited a remarkable degree of tentativeness and caution, so that its pursuit of human rights goals was anything but "single-minded." Relatively few governments were considered to be "engaged in a consistent pattern of gross [human rights] violations." Security assistance was actually cut off to even fewer, because other U.S. interests were often found to outweigh human rights concerns under the exception for "extraordinary circumstances." Moreover, in some instances, the Carter administration adopted a highly strained reading of the statute which, although not contrary to its literal terms, produced a result contrary to congressional intent. In other cases, the language was simply disregarded, so that decisions violated even the letter of the law.

\section{Fear of Finding}

Perhaps the most remarkable evidence of the administration's conservative approach to section 502B was its policy never to determine formally, even in a classified decision, that a particular government was engaged in grciss abuses. ${ }^{88}$ The primary reason for this policy was the belief that such a determination, even if classified, would inevitably be leaked to the press and become generally known. ${ }^{89}$ It was feared that each country named would then consider itself publicly insulted, with consequent damage to our bilateral relationship. In addition, there was concern that once such a finding was revealed, the freedom to alter it might be severely constrained by public political presisures. Any attempt to name a country as a "gross violator" would raise the ire of defenseminded conservatives who did not want military ties cut off. Any attempt to

\footnotetext{
${ }^{86}$ See generally Kirkpatrick, Dictatorships and Double Standards, COMMENTARY, Nov. 1979, at $34-45$.

${ }^{87}$ Walsh, Carter Asserts Human Rights Is "Soul of our Foreign Policy," Wash. Post, Dec. 7, 1978 , at $\mathrm{A2}$, col. 4 .

${ }^{88}$ Cf. CRS, Human Rights STUdY, supra note 15, at 2, 6. The Congressional Retsearch Service concluded that "there was great reluctance formally to identify governments that engaged in consistent patterns of gross violations of ... human rights. . . The administration has avoided identifying countries as gross and consistent violators of human rights. . . ."Ibid.

${ }^{89}$ Halperin makes this point clear:
}

At the top levels of the American government the belief is held that anything of importance ... will be leaked to the press by some participant unhappy with the drift of presidential decisions. Because this belief is so widely held, it tends to infuence significantly the way issues are handled in the executive branch. Often an option under consideration will be rejected on the grounds that it could not be implemented before it was leaked and not successfully implemented unless put into effect before it leaked.

M. HALPERIN, supra note 13, at 192-93. 
change the finding because a country had improved conditions would be subject to intense scrutiny by human rights partisans to determine whether the supposed improvements were cosmetic or genuine. Thus, maximum flexibility required that no country be formally found to be prohibited from receiving security assistance under section 502B. ${ }^{90}$

In practice, the Secretary of State had to resist pressures both from Congress and within his own Department to make such findings. ${ }^{91}$ Administration representatives repeatedly refused congressional requests for a list of governments considered to be engaged in gross abuses, stating that it was administration policy not to draw up such a list. ${ }^{92}$ Within the Department, the Secretary of State sought to avoid explaining the reason for decisions on security assistance either in writing or even informally. When he resolved a dispute, he often communicated simply whether the request was approved or disapproved and little more. Particularly in cases of disapproval, the Secretary strenuously avoided ever stating that it was required by section 502B since such a statement would have meant that the government in question was considered to be engaged "in a consistent pattern of gross violations of human rights."

\section{The Development of a Body of Precedents}

Because of the administration's policy of not making explicit findings under section $502 \mathrm{~B}$, the legal basis for particular outcomes was rarely made clear to the contesting bureaus. ${ }^{93}$ It was often difficult to say in a particular case exactly why the Secretary of State believed that section 502B did or did not apply. If security assistance was approved, it might have been because the government was found not to be engaged in gross abuses; or that it was, but fit within the extraordinary circumstances exception; or that some other consideration, not explicitly mentioned in section $502 \mathrm{~B}$, was read into the statute and had determined the outcome. If security assistance was disapproved, it was never formally stated that this was because the proposed recipient was considered to be a gross violator under section $502 \mathrm{~B}$.

\footnotetext{
40 The Congressional Research Service concluded: "Specificity with respect to principles guiding human rights initiatives. . . has been seen by some as threatening to unduly limit flexibility in application of policy. Indeed, strong arguments can be made for the benefits of vagueness in policy definition where policy evolution and change seem likely." CRS, HuMAN RiGHTS STUDY, supra note 15 , at 49.

${ }^{91} C f$. $2 b z$. (explicit identification of specific countries strangly resisted at high levels within Department of State).

${ }_{92}$ In 1978 Congress acquiesced in this practice of refusing to make public such a list. The conference report on the 1978 legislation transforming section 502B into a binding legal requirement also explained that Congress did not "intend to require the executive branch to publicly identify those countries which it considers to be consistent violators." H.R. REP. No. 95-1546, supra note 41, at 27, [1978] U.S. CoDE CoNG. \& AD. News at 1874.

${ }_{93}$ The Congressional Research Service concluded on the basis of extensive interviews with Carter administration officials that "each case . . . seemed to be reviewed on its own merit, and individual decisions did not seem to produce principles on which subsequent cases could be decided." CRS, HuMAN Rights STUdY, supra note 15, at 2 . It further noted that "[t]he case-by-case approach followed by the Administration, combined with the reluctance to articulate-indeed, apparently even to formulate-principles of sufficient specificity to guide individual decisions, contributed to congressional concern." Id. at 3 .
} 
Owing to this lack of clear direction and the persistence with which both the Human Rights Bureau and the regional bureaus pursued their respective objectives, a considerable volume of action memorandums on security assistance issues were produced during the first half of the Carter administration. After the initial period, however, when a body of precedents was created: the amount of "litigation" began to decrease ${ }^{94}$ as contesting bureaus inferred by the pattern of outcomes how the Secretary of State was interpreting section $502 \mathrm{~B} .{ }^{95}$ The major issues of interpretation are discussed below. The three key questions were:

(1) When was a foreign government considered to be en;aged "in a consistent pattern of gross violations of internationally recognized human rights"?

(2) What U.S. interests constituted "extraordinary circumstances"?

(3) What was encompassed by the category "security assistance"?

1. Gross Violations. The threshold issue under section $502 \mathrm{~B}$ is whether a particular government "engages in a consistent pattern of gross violations of internationally recognized human rights." At the outset, it is necessary to explain that the issue never arose with respect to many governments that appear to have practiced gross abuses. The question whether section 502B might apply to them was never raised because they were never seriously considered for security assistance for a variety of reasons other than human rights. For example, Communist countries (the Soviet Union and its Warsaw Pact neighbors, and Cambodia, China, and Vietnam) and Soviet client states (such as Afghanistan, Cuba, Ethiopia, Iraq, Libya, and South Yemen) were barred for national security reasons. ${ }^{96}$ In addition, a number of countries (for example, Chile $^{97}$ and South Africa ${ }^{98}$ ) were already prohibited by other legal requirements from receiving security assistance.

After these countries were eliminated, approximately 70 remained that were

${ }^{94} \mathrm{By}$ the end of 1978 , in the view of the Congressional Research Service, "[ojur interviews suggest that the most intense period of bureaucratic conflict over human rights has new passed and that ways have recently been sought for reducing the amount of time and attention required for managing human rights decisions." Id. at 67.

${ }^{95}$ In the view of the Congressional Research Service, "these patterns have evolved out of a continuing-and often highly contentious-set of incremental policy struggles between competing elements of the foreign policy decisionmaking structure." Id. at 66.

${ }^{96}$ In addition, there is a statutory bar. Except in exceptional circumstances, the F'resident may not provide Communist countries with security assistance. 22 U.S.C. \$2370(f) (1976).

${ }^{97}$ International Security Assistance and Arms Export Control Act of 1976, \$406, 90 Stat. 758, as amended by International Security Assistance Act of 1978, $\$ 10(b)(5), 12(c)(5), 92$ Stat. 735, 737 (1978).

${ }^{98}$ Under General Assembly Resolution 2624, the United Nations called upon its me mber nations to implement fully the provisions of Security Council Resolution 282 in light of the apartheid practices of the Government of South Africa. GA Res. 2624 (XXV) (1970). Under Resolution 282, the Security Council called upon the member states of the General Assembly fully to embargo the supplying of arms, spare parts, and any forms of military assistance to the Government of South Africa. SC Res. 282, 25 UN SCOR at 12, UN Doc. S/INF/25 (1970). The Inited States had already instituted such an embargo, prior to 1970. In 1963, President John F. Kennedy announced that the United States unilaterally would not sell arms to South Africa as long as it practiced apartheid. A. Schlesinger, JR., A Thousand Days 583 (1965). 
seriously considered for military aid and arms sales. A narrow reading of the "gross violations" language was adopted, so that, in the end, only about 12 of the 70 were thought to fall within it. While in some respects the narrow reading was consistent with the congressional purpose, in others it appeared to subvert the intended meaning of the statute. The narrow reading was derived from the way that the four basic elements of the category were interpreted. First, there must be violations of "internationally recognized human rights." Second, the violations must be "gross." Third, the frequency of violations must result in a "consistent pattern." Fourth, the government itself must be engaged, which is to say, responsible for the violations.

A definition of internationally recognized human rights is contained in section 502B itself. According to subsection (d)(1), this term "includes torture or cruel, inhuman, or degrading treatment or punishment, prolonged detention without charges and trial, and other flagrant denial of the right to life, liberty, or the security of the person" (emphasis added). 99 The use of the word "includes" suggests that the list of abusive practices in the statute is not meant to be allencompassing. The formulation is open-ended and holds out the distinct possibility that violations other than those listed might trigger the termination of security assistance. However, the statute's sponsor, Representative Fraser, opposed this view, and the legislative history contains strong evidence that Congress wanted the quoted language to be interpreted narrowly rather than expansively. In 1974, when section 502B was first enacted, Representative Gross (R., Iowa) offered an amendment (which was defeated) to expand the coverage to all human rights generally. ${ }^{100}$ The rejection of the Gross amendment implied that Congress intended to focus only on one narrow, albeit very important, category of human rights abuses involving torture, arbitrary imprisonment, and cruel and inhuman punishment.

The Carter administration followed Fraser's interpretation. In its decisions on security assistance, it was careful to go no further than required by the abuses specifically listed in subsection (d)(1). A government was considered to fall within it only when it practiced arbitrary imprisonment, torture, or summary execution of relatively large numbers of its own people. That a government was authoritarian, denied basic civil and political liberties, or failed to promote basic economic and social rights was not, by itself, enough to invoke the statutory prohibition on military ties.

The second element, that the violations must be "gross," was read to mean that they must be significant in their impact. For example, although arbitrary imprisonment is one of the listed violations, detention without charges for several

${ }^{94} 22$ U.S.C. $\$ 2304$ (d)(1) (Supp. III 1979) (emphasis added). Under the International Security and Development Cooperation Act of 1980, Pub. L. No. 96-533, \$701(b), 94 Stat. 3156 (1980), Congress added a clause on "disappearances" because "[d]isappeared persons currently constitute one of the most serious gross violations of human rights and of the principle of the Universal Declaration of Human Rights." H.R. REP. No. 96-884 (pt. 1), 96th Cong., 2d Sess. 54 (1980), reprnted in [1981] U.S. CODE CONG. \& AD. NEws 10,815, 10,870.

${ }^{100}$ Under Representative Gross' amendment, security assistance could not be provided or defense articles sold to a country until "the President certifies to the Congress that such country is satisfactorily observing internationally recognized standards of human rights with respect to its citizens." 120 Cong. REc. 39,135 (1974). The House of Representatives rejected the amendment by voice vote. Id at 39,137 . 
days was not considered "gross" because of the relatively brief period of confinement.

Third, the element of a "consistent pattern" was held to mean that abuses had to be significant in number and recurrent. Isolated instances of torture or summary execution, while certainly gross abuses, would not trigger termination of security assistance under section 502B. For example, the repoited imprisonment and torture of several dozen labor leaders in Tunisia was considered not to be sufficient by itself to constitute a "consistent pattern." This reading of "consistent pattern" is not unreasonable, given Representative Fraser's concern that the statute not reach too broadly. However, an additional gloss was put on this language that seems at odds with the congressional purpose.

Even when gross abuses were significant in number and recurrent, the "pattern" was occasionally held not to be "consistent," if steps were taken to stop some abuses. Perhaps the most dramatic example of the use of this interpretation to avoid a section 502B problem is the case of Indonesia. At the beginning of 1977, its Government appeared to be engaged in gross abuses on two fronts. In Indonesia proper, it was holding thirty thousand prisoners, in detention since the 1966 civil war, on suspicion of Communist syrnpathies. ${ }^{101}$ At the same time, it was annexing East Timor and in the process of exterminating perhaps one hundred thousand or more civilian inhabitants of that island. ${ }^{102}$ The adoption and implementation of a plan for freeing the thirty thousand prisoners within 3 years was considered sufficient to "break" the consistent pattern, notwithstanding evidence of continuing gross abuses on a large scale in East Timor.

Ordinarily, the fourth element, that the government itself engage in or be responsible for the violations, was not an issue if the other criteria were already met. In most instances, governments did not deny responsibility but sought to justify the abuses to U.S. officials on grounds of national security, fighting terrorism, anticommunism, and the like. Absent such an admission, however, the word "engages" was read to require "approval" by the highest ranking officials of the government in question, even if they lacked effective control over the military forces committing the abuses.

For example, in 1980 the Department of State argued that the Government of El Salvador was not one that "engages" in admittedly gross abuses committed with the approval of military commanders, because of evidence that the fiveperson ruling junta may not have approved. ${ }^{103}$ This reading of the word "engages" was highly disingenuous, because any security assistance frovided to the Government of El Salvador would have been delivered to the military

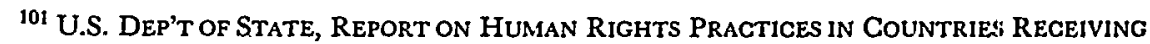
U.S. AID: REPORT SUBMITTED TO THE SENATE COMM. ON FOREIGN RELATIONS ANC'THE HOUSE CoMm. ON Foreign AfFaIRS, 95th Cong., 2d Sess. 360-63 (Joint Comm. Print 1979).

102 See supra note 66.

${ }^{103}$ In response to a specific congressional inquiry, the Department of State asserted that the new Government in El Salvador was attempting to curb human rights violations by the military. See Letter from J. Brian Atwood, Assistant Secretary for Congressional Relations, to the Honorable Matthew F. McHugh (Oct. 22, 1980) (copy on file with the author). For a critique of this position, see Americans for Democratic Action, Security Assistance and El Saflador: What the Law Says (unpub., copy available from Americans for Democratic Action, Washlington, D.C.). 
commanders and their forces. Therefore, for purposes of the statute, they should have been considered as the "government" that "engages" whether or not the formal, but powerless, political authorities had approved their practices.

Which governments were considered to be engaged "in gross violations"? While the Carter administration never formally determined, privately or publicly, that any government was a "gross violator" under section 502B, this question was directly addressed in action memorandums and departmental meetings before decisions on security assistance were made by the Secretary of State. Thus, whether governments did or did not fit within the category was constantly in the forefront of the decision maker's mind. He was aware that it was contrary to section 502B to approve security assistance to a "gross violator," absent extraordinary circumstances. His decisions on a case-by-case basis formed a pattern reflecting his assessment of human rights practices of particular governments; one can infer from this pattern which countries were implicitly regarded as falling within the "gross violator" category.

The approximately 70 countries seriously considered for military aid and arms sales were divided into three basic categories. The first included a significant number of functioning democracies with good records of respect for basic human rights. As a result, such governments were thought not to raise a serious human rights question under section 502B. Among them were the Governments of Western Europe, Australia, New Zealand, and Japan, and a number of Third World Governments, including Botswana, Colombia, Costa Rica, Kenya, and Venezuela. A second category comprised governments that were authoritarian and, on occasion, might engage in the gross abuses described in subsection (d)(1). When the practices of such governments were closely examined, the frequency of abuses was considered too low to constitute a "consistent pattern." Among the countries in this group were Morocco, Singapore, Taiwan, Tunisia, and Thailand. The third category consisted of governments practicing torture, arbitrary detention, or summary execution on a significant scale that were therefore considered to be engaged in gross violations under the statute. Although no formal "hit" list of countries in the third category was ever prepared, it could easily have been inferred from the pattern of decisions on specific security assistance issues raised in action memorandums. ${ }^{104}$ By the middle of Carter's term, the implied list would have looked more or less as follows:

$\begin{array}{ll}\text { Latin America: } & \text { Argentina, Bolivia, El Salvador, Guatemala, Haiti, } \\ & \text { Nicaragua, Paraguay, Uruguay } \\ \text { East Asia: } & \text { the Philippines, South Korea } \\ \text { The Middle East: } & \text { Iran } \\ \text { Africa: } & \text { Zaire }\end{array}$

Changed circumstances in particular countries caused the implied list to be modified at certain points. For example, Bolivia was not on the list when elected

104 Cf CRS, HUMAN RighTS STUDY, supra note 15, at 39 (most officials seem to agree that countries such as Korea, the Philippines, and Iran have violated certain internationally recognized human rights); id. at 58-59 (governmental policies of widespread killings and torture are widely seen as repugnant; such conditions have existed in Chile, Argentina, Uruguay, and Nicaragua at times during past 5 years). 
civilian Governments were in power in 1977 and 1979, but was or it following military coups in 1978 and $1980 .{ }^{105}$ Nicaragua was on it when Anastasio Somoza was in power and off it for at least the initial period following the revolution. As noted, the administration argued in 1980 that the rew Government of El Salvador could not be considered responsible for military abuses.

2. Extraordinary Circumstances. The Carter administration always gave considerable weight to arguments that other U.S. interests might require continuation of security assistance, even when the government in question was thought to be a "gross violator." Thus, the charge that its pursuit of human rights was "single-minded" and to the exclusion of other interests was far wide of the mark. If anything, the administration gave excessive credence to claims that some specific foreign policy objective would and could be promoted only if security assistance were provided, and often failed to subject such claims to rigorous analysis.

The administration did require some showing of a substantial and specific interest before the exception for extraordinary circumstances was available. A mere desire for cordial relations, without more, was never held sufficient to constitute "extraordinary circumstances." However, once a specific interest of some substantiality was cited, the exception was usually invoked. Because of the liberal use made of the exception for "extraordinary circumstances," the number of countries subject to a section 502B cutoff was quite modest. In the end, human rights concerns resulted in the termination of security assistance to only eight countries, all in Latin America: Argentina, Bolivia, El Salvador, Guatemala, Haiti, Nicaragua, Paraguay, and Uruguay.

Extraordinary circumstances were found for all of the other countries considered to be gross violators. Thus, Indonesia (although technically not on the list) was a key member of ASEAN (the pro-Western association of Southeast Asian countries) and important to countering Soviet and Vietnamese influence in the region. Iran was judged critical because it shared a long border with the Soviet Union, was a major supplier of oil to the West, and defended our strategic interests in the Persian Gulf. Military ties with South Korea were deemed essential to deterring the threat of an invasion from the north. Military bases in the Philippines were judged critical to the United States and a security assistance relationship essential to keeping the bases. Finally, Zaire, the third largest country by area in Africa, was the source of nearly all the West's cobalt, a material crucial to the performance of high-performance jet engines. ${ }^{106}$

${ }^{105}$ See 80 DEP'T STATE BuLL., No. 2042, Sept. 1980, at 71 (statement of Edmurd S. Muskie, Secretary of State) (United States terminating military assistance to emphasize concern about recent coup d'état in Bolivia).

${ }^{106}$ Early on, Secretary of State Vance announced that the administration would continue to provide security assistance to South Korea, the Philippines, and Indonesia, despite section 502B, for reasons of national security. Gwertzman, U.S. Cuts Foreign Aid in Rights Violations; Sauth Korea Exempt, N.Y. Times, Feb. 25, 1977, at A1, col. 6.

After Ronald Reagan won the presidential election in November 1980, the Human Rights Bureau compiled a report on the statutory human rights provisions and the policies and procedures under which they had been implemented during the Carter administration. In the security assistance section, the report stated: "Military assistance including weapons sales is denied to countries whose governments torture, summarily execute, and/or arbitrarily imprison appreciable numbers of their citizens, unless national security interests nonetheless dictate such assistance. Examples of the latter exceptions: Indonesia, the Philippines, South Korea and Zaire." U.S. Dep't of State, Project Legacy, Tab F, at 3 (1981) (emphasis added) (copy on file with the author). 
No claims of similar magnitude were made for United States interests in Latin American countries on the list. None supplied a critical resource, shared a border with the Soviets, or acted as a special surrogate to defend U.S. interests in the entire region. The Latin American Bureau did argue that Argentina fit within the exception, asserting that the need to cooperate in policing sea lanes of the South Atlantic to counter a Soviet naval threat constituted "extraordinary circumstances." This position, however, was rejected because the threat was not viewed as extraordinary and, in any case, alternative means existed to counter it. ${ }^{107}$

In all the cases where a substantial interest was found, the administration assumed, mostly without question, that arms sales and military aid would automatically help secure it. In no case did the administration seriously consider that such approval might actually make the interest less attainable, particularly over the longer run. For example, during 1977 and 1978, the United States approved the sale of billions of dollars of sophisticated weaponry to Iran under the Shah. The enormous cost of these arms fed the Iranian belief that the country's oil wealth was being wasted to benefit U.S. defense companies, which reinforced anti-American feelings in Iran. ${ }^{108}$ Similarly, in 1978, the U.S. Government signed an agreement tripling military aid to the Philippines in order to make more secure its military bases there. But the net effect of this action was probably to make the bases less secure because it associated the United States with the unpopular, ineffective, and corrupt Marcos dictatorship. ${ }^{109}$

Why the failure to ask what seems to be an obvious question: whether security assistance might, in some cases, not promote or even make it harder to achieve desired objectives? On one level, the explanation is the lack of an adequate bureaucratic mechanism for raising the issue. The career bureaucracy, given its "clientist" perspective, was hardly likely to ask whether a program of military aid or arms sales might cause more harm than good and virtually never did. The Bureau of Human Rights was simply not equipped to do so. With a professional staff of only about 20 , it had its hands full simply trying to collect and present information about human rights practices. Raising this other issue would have required detailed knowledge about the internal political dynamics of other countries and the bureau generally lacked sufficient independent data to challenge the regional bureaus. Moreover, on those occasions when it tried (as, for example, in the case of arms sales to Iran), it was viewed by the Secretary of State as going beyond the area of its mandate. While the bureau could be expected to have detailed knowledge about human rights abuses, judgments about national security were to be left to the experts in the regional bureaus who knew best.

At another level, the failure to consider such issues assumes a fundamental conflict between the pursuit of morality (human rights) and the pursuit of selfinterest (national security). Such a dichotomy is implicit in the term Realpolitik, which connotes the idea that moral goals have no place in a rationally selfinterested foreign policy. Whether one accepts or rejects the dichotomy depends

\footnotetext{
${ }^{107}$ Cf Anderson, Argentina Is No Ally, N.Y. Times, Aug. 2, 1980, at A21, cols. 1-3.

${ }^{108}$ See generally S. Cohen, Who Lost Iran, supra note 68.

${ }^{209}$ See generally S. Cohen, Keeping An Unpopular Despot at Arm's Length, Wash. Post, Feb. 22 , 1981, at C4, cols. 1-6.
} 
largely on one's political and moral values. It is noteworthy, however, that the drafters of section 502B firmly rejected it. The 1974 Fraser subcommittee report stated, "consideration for human rights in foreign policy is both morally imperative and practically necessary."110 This view is reflected in the language of the section 502B exception. Not only must "extraordinary circumstances" exist, but in addition it must be found that providing security assistance is, "on all the facts," in the national interest. ${ }^{111}$ This latter phrase suggests the kind of inquiry that should be made before invoking the exception and that the Carter administration failed to make.

3. Security Assistance. Even when a government was considered to be a "gross violator" and there were no "extraordinary circumstances," the termination of security assistance by the Carter administration was at timies less than complete. Special exceptions to the general rule of subsection (a)(2) were created, most notably for the sale of certain military items to "gross violators" when it was believed that approval might induce human rights progress. These exceptions were not set out in the statute and therefore went beyond the letter of the law. Moreover, in at least one instance, involving Argentina, the exceptions were abused in a way that seriously undermined the purpose of section 502B. The exceptions arose in the course of interpreting the term "security assistance," which includes both the gift of military aid and the sale of arms. ${ }^{112}$ Because each involves somewhat different considerations, they are discussed separately below.

The Carter administration's first application of section 502B to military aid marked a sharp departure from the Nixon-Ford policies of ignoring; the statute altogether. Shortly after taking office, Secretary of State Vance expressed support for the principle that human rights concerns should affect decisions on security assistance. He also announced that, under section 502B, the budget for fiscal year 1978 would include no military aid for Ethiopia or Uruguay and that amounts for Argentina would fall by 50 percent. ${ }^{113}$

At the same time, the administration did propose military aid for a number of other governments that appeared to be engaged in gross violaticns and not to qualify for the extraordinary circumstances exception-among them, El Salvador, Guatemala, Nicaragua, and Paraguay. However, most of the funds requested and authorized for these Latin American Governments in the budget for fiscal year 1978 were never disbursed. Moreover, beginning with the fiscal

${ }^{110}$ Fraser REPORT, supra note 22, at 9 (emphasis added).

${ }^{111}$ See 22 U.S.C. $\$ 2304$ (c)(1)(C)(ii) (Supp. III 1979).

112 Under 22 U.S.C. \$2304(d)(2) (Supp. III 1979), security assistance is defined to include grant military aid "sales of defense articles or services, extensions of credits . . . , and guarantees of loans under the Arms Export Control Act."

113 See Foreign Assistance Legislation for Fiscal Year 1978 (Part 1): Hearings Before the House Comm. on International Relations, 95th Cong., 1st Sess. 1-34 (testimony of Cyrus Vance, Secretary of State); Oberdorfer, In Rights Push, Vance Asks Culs in 3 Nations' Aid, Wash. F'ost, Feb. 25, 1977, at A6, col. 4. In response, Argentina's military Government denounced the Carter administration's decision to reduce the military aid package. De Onis, Argentina Says Carler Interferes, N.Y. Times, March 1, 1977, at A6, col. 1. The Government of Argentina ultimately decided to reject the proposed military assistance. De Onis, Argentina and Uruguay Reject U.S. Assistance Linked to Human Rights, id., March 2, 1977, at A10, col. 5. 
year 1979 and continuing through fiscal year 1981, essentially no military aid was provided for Governments on the implied "hit" list of Latin American countries engaged in gross violations for which no extraordinary circumstances were found to exist. ${ }^{114}$ Exceptions to this rule were made on a few occasions. Military aid was requested for Bolivia when its Government seemed to be making progress in curbing human rights abuses, but later the administration refused to disburse the aid funds after a military coup led to a dramatic increase in violations. ${ }^{15}$ In addition, a small amount of military aid destined for Haiti was justified as intended for the purchase of air-sea rescue equipment.

More troubling was a decision to request a quarter of a million dollars in military training funds for Guatemala in the fiscal year 1981. In the few years preceding submission of the budget, Guatemalan military forces were believed to have killed over five thousand people, including leaders of the moderate political opposition. ${ }^{16}$ The Secretary of State's decision to go ahead with the aid package, notwithstanding these facts, probably reflected his own view that military training generally should not be reduced for human rights reasons, as well as a desire not to refuse the newly appointed head of the Latin American Bureau who had fought hard for the aid. Yet the decision seemed to be clearly contrary to section 502B. Certainly, Congress held this view, as both House and Senate committees voted overwhelmingly for country-specific legislation to remove the Guatemala package from the 1981 military aid budget. ${ }^{117}$

The arms sales component of security assistance is defined by subsection (d)(2) as including all sales of "defense items" under the Arms Export Control Act, and the term "defense items" is given a broad scope by the Act. ${ }^{118}$ It includes not only weapons such as tanks, guns, jet fighters, and naval warships, but also a host of support and auxiliary equipment such as communications equipment, unarmed military transports, and radars. ${ }^{119}$ Moreover, any services provided in connection with such equipment are also covered. ${ }^{120}$

The Carter administration did not automatically terminate all sales of defense items when a government was considered to be engaged in "gross violations" and "extraordinary circumstances" were not found. It adopted instead a "flexible" approach and broke up the panoply of defense items subject to the Arms

\footnotetext{
114 Each year prior to Congress's consideration of the authorization and appropriation bills for military aid for the upcoming fiscal year, the Department of State submits to Congress a "Congressional Presentation Document," which details the administration's request for military aid grants and military sales credits. To review the Carter administration's requests in fiscal years 1978 through 1981, see U.S. Dep'T OF STATE, Congressional PRESENTATION For Security AssisTANCE PROGRAM FY 1978 (1977); CONGRESSIONAL PRESENTATION FOR . . . FY 1979 (1978); CONGRESSIONAL PRESENTATION FOR . . FY 1980 (1979); CONGRESSIONAL PRESENTATION FOR . . FY 1981 (1980).

${ }^{115}$ See note 105 supra.

${ }^{116}$ Hoge, Repression Increases in Guatemala as U.S. Is Seeking to Improve Ties, N.Y. Times, May 3, 1981, at 1, cols. 2-3. See also Hoge, Guatemala Keeps a Step Ahead of Rights Gunmen, N.Y. Times, May 4, 1981, at 2, col. 2.

${ }^{117}$ Morgan, Panel Rebuffs U.S. Bid to Relax a Rights Sanction, Wash. Post, March 23, 1979, at $\mathrm{A} 2$, col. 3.

${ }^{118}$ See 22 U.S.C. $\$ 2794(3)(1976) . \quad 119$ Id. $\$ 2794(3)(\mathrm{A})-(\mathrm{B})$.

${ }^{120} I d . \$ 2794(4)$ and $(7)$.
} 
Export Control Act (and therefore section 502B) into a number of subcategories:

(1) New weapons: tanks, artillery, fighters and bombers, and naval warships;

(2) Spare parts for previously acquired weapons;

(3) Support equipment: trucks, unarmed aircraft and ships, radios, and radars; and

(4) Safety-related items: ambulance aircraft and air-sea rescue equipment.

New weapons were consistently withheld, whenever requested. On the other hand, safety-related items were almost never denied, and spare parts and support equipment were approved for sale on numerous occasions. ${ }^{121}$ These exceptions, of course, are contrary to the literal language of section 502B, and the regional bureaus advocating approval felt it necessary to construct a legal rationale for this position. The exception for safety-related items was justified in terms of the underlying purpose of the statute, that is, the protection of basic human rights. To disapprove the sale of equipment devoted to rescuing lives, it was argued, would defeat the basic goals of the statute. Items in the two middle categories (spare parts for weapons and support equipmen:) were approved on the basis of a different, but related, consideration: that a sale of defense items was on occasion needed to encourage another government to improve human rights conditions, and that spare parts and support equipment (as contrasted with new weapons) were an acceptable means of providing an inducement. In effect, section 502B was read to mean that Congress was concerned most about actual weapons and would be willing to permit the sale of other items when it was reasonable to suppose that it would lead to human rights improvements.

While the exception for safety-related items appears reasonable because of the direct connection with saving lives, that for spare parts and support items is fraught with danger. Such items are as critical to military performance as weapons themselves. Moreover, spare parts and support equipment typically make up a large part of a military's total acquisitions. Thus, to continue to approve such items is to continue a significant military supply relationship between the United States and the recipient. This danger may be acceptable if there are definite advantages to be gained in terms of human rights improvements. The risk, however, is that exceptions will be granted on the basis of unrealistic hopes that improvements will follow. If that turns out to be the case, then making these exceptions could undermine the purposes of section 502B.

The inducement rationale was invoked to justify spares and support items for five Latin American countries: Argentina, El Salvador, Guatemala, Para-

121 See U.S. Dep't of State, A Review of U.S. Human Rights Policy and Application of Laws Affecting Security and Economic Assistance in Latin America (unpub. document on file with the author). The Assistant Secretary of State for Human Rights and Humanitarian Affairs, Patricia Derian, also confirmed this decision in a speech at Dade Community College in Miami, Florida, on Oct. 7, 1980. 
guay, and Uruguay. ${ }^{122}$ While in no case was there clear evidence that making exceptions helped induce a government to improve human rights conditions, it also appears that, for the latter four countries, approvals did little harm, perhaps because relatively small dollar amounts were involved. ${ }^{123}$ However, in the case of Argentina the exception appears to have been abused. Argentina was considered to be one of the most serious human rights violators in the nonCommunist world because of the torture and summary execution of thousands of political dissidents and other "undesirables" by government security forces. ${ }^{124}$

During 1977 and 1978, Argentina submitted requests to purchase about $\$ 200$ million in defense items from the United States. The Latin American Bureau argued that approval of spares and support items was justified under section 502B as not involving new weapons and as an inducement for Argentina to improve human rights conditions. The Bureau of Human Rights was opposed on the grounds that section 502B contained no exception for spare parts and support items and that, in any case, approval was unlikely to have the desired effect. The Secretary of State found the former's arguments persuasive and approved the sale of nearly $\$ 120$ million in weapons. ${ }^{125}$

It now appears that the approval of spares and support items was based on unrealistic hopes and did not elicit steps to curb abuses in Argentina. Human rights violations continued at a high level throughout the period during which these items were sold. ${ }^{126}$ The dollar value of U.S. arms sales to Argentina in 1978 was actually higher than in any prior year. ${ }^{127}$ Consequently, the Argentine Government may have believed the American executive branch to be deeply divided over whether security assistance to Argentina should be affected by its human rights practices, and this belief may have substantially reduced the impact of American human rights pressures on Argentina during 1977 and most of 1978 . The level of abuses there began to decline only after a statutory embargo on all security assistance, enacted by Congress, went into effect on October 1, 1978. ${ }^{128}$ Thus, the numerous exceptions for spare parts and support equipment before that date were not only of doubtful legality, but also undermined the basic purpose of the legislation.

122 See note 121 supra.

123 To review the levels of arms sold to Argentina, El Salvador, Guatemala, Paraguay, and Uruguay, see Defense Securiry Assistance Agency, DeP'T of Defense, Foreign Military SAlES AND Assistance Facts 1980, at 6, 34 [hereinafter cited as MilitaRY Sales aNd AssisTANCE FACTS].

124 See note 67 supra.

125 De Young \& Krause, Our Mixed Signals on Human Rights in Argentina, Wash. Post, Oct. 29,1978 , at $\mathrm{C} 1$ and 2 , cols. 4-5, 1-2.

126 See supra note 67 .

127 Milit ARY SAles AND Assistance FACTS, supra note 123 , at 6,34 .

${ }^{128}$ See text accompanying and note 52, supra. In its initial draft, the embargo legislation was to have become effective 1 year earlier, on Oct. 1, 1977. The congressional sponsors agreed to defer the effective date for 1 year after the Department of State complained that a statutory ban (which could be changed only by new congressional action) would destroy its ability to respond quickly to changed conditions. The Department promised, in return, that no arms sales would be approved in the interım unless Argentina first demonstrated significant human rights progress. The approval of a large volume of sales during the year before the cut-off date, without any such progress, violated this explicit understanding between the Executive and members of Congress. 


\section{The Congressional Response}

It should be obvious from the record that the Carter administration did much more than its predecessors to implement section 502B. The procedural requirements that the statute be applied to decisions on providing security assistance and that the Human Rights Bureau be involved were carried out in a reasonable manner. Human rights concerns were given a hearing at nearly all stages in the process of providing military aid and selling arms and the Bureau of Human Rights was afforded a reasonably full opportunity to make its views known through action memorandums. Sales of new weapons were banned to eight Latin American countries. In addition, the same countries, with a few exceptions, received little or no military aid for fiscal years 1978 through 1981. The decision to withhold military aid and weapons on human rights grounds, even from this small number of governments, was a radical departure from the practice of past administrations.

Yet, if the standard of comparison is not the practice of prior administrations, but instead the substantive rule of section 502B, the record of implementation appears much more modest. The Carter administration exhibited considerable flexibility in applying the law to actual decisions, and at some points its decisions appear to have been contrary to the substantive rule. After a few positive steps, a "pattern" of abuse was held to be no longer "consistent" even if widespread torture, arbitrary imprisonment, and summary execution continued. Liberal and uncritical use was made by the Executive of the exception for "extraordinary circumstances," so that security assistance was actually terminated only to a limited number of countries, all in Latin America. Especially troublesome were the reading of the term "defense items" to create an exception for spares and support items, not provided for in the statute, and the abuse of that exception in the case of Argentina.

During 1977 and 1978, members of Congress, particularly on the House International Relations Committee, expressed unhappiness over the administration's performance in the implementation of section 502B. Some romplained about the exceptions made under subsection (a)(2) for spares and support items. Others felt that there had been excessive use of the exception for "extraordinary circumstances" and specifically mentioned the administration's failure to reduce military aid for the Philippines, South Korea, and Zaire. ${ }^{129}$ In part because so many exceptions were being made, in 1978 Congress eliminated the introductory phrase, "it is the policy of the United States," in order to transform section $502 \mathrm{~B}(\mathrm{a})(2)$ into a binding legal requirement. ${ }^{130}$ Surprisingly, however, the strengthening of the basic rule on military aid and arms sales hacl no impact on the Carter administration. There was no diminution in the scope of exceptions either for "extraordinary circumstances" or for spares and support items. The change in the substantive law alone was apparently not enough to influence the Executive to alter its behavior.

\footnotetext{
${ }^{129}$ See, e.g., Human Rights in the Philippines, Recent Developments: Hearingss Before the Subcomm. on International Organizations of the House Comm. on International Rulations, 95th Cong., 2d Sess. (1978).

${ }^{130}$ See International Security Assistance Act of 1978, §6(a), 92 Stat. 731 (1978).
} 


\section{CONCLUSIONS}

What are the lessons to be drawn for implementation by the Executive when Congress attempts to legislate foreign policy? The history of section 502B is a case study of executive frustration of congressionally mandated foreign policy and underlines the need, particularly with this kind of legislation, for clearer directives, less discretion, and more assiduous congressional oversight. While these observations emerge from experience in the human rights area, they are relevant to other congressional attempts to influence the Executive's conduct of foreign policy. They are especially apt when congressional objectives may require decisions that displease particular governments and that will therefore be resisted by the Foreign Service bureaucracy whose paramount interest is maintaining cordial relations. For example, conclusions about the effectiveness of legislation conditioning security assistance on human rights practices are likely to be highly relevant to legislation conditioning nuclear exports on practices with respect to nuclear proliferation.

Congress has the most decisive impact when its directives allow the Executive no discretion at all, as in the country-specific legislation stating precisely which governments are to be denied military aid and arms sales on human rights grounds. On the other hand, whenever the statute permits any exercise of discretion at all, the career Foreign Service is likely to use it to attempt to thwart congressional objectives.

Precision in a statute, of course, is a matter of degree and some provisions allow considerably more discretion than others. No one should be surprised at the bureaucracy's lack of enthusiasm for implementing a vaguely worded general directive. Given its "clientist" impulse, the Foreign Service can be expected, for example, to ignore a statutory directive that the United States "disassociate itself from governments that violate internationally recognized human rights." In such a provision, the means of disassociation are unspecified and left to the diplomat to choose. Disassociation, moreover, is set forth as only one foreign policy goal, which presumably may give way to other objectives when, in the judgment of the bureaucracy, the national interest so requires.

But compared to such a hypothetical statute, section 502B is a model of precision. The means for achieving disassociation are particularized both by the clear, unambiguous definition of security assistance and by the requirement that it be denied in specific cases. The disassociation objective is ranked relative to other foreign policy goals, and it is to be paramount whenever the other government "engages in a consistent pattern of gross violations" and "extraordinary circumstances" are absent. While both these phrases do have considerable elasticity, it should also be clear that the arbitrary imprisonment, summary execution, and torture of thousands of people amount to a "consistent pattern" and that a mere desire for cordial relations without more is not "extraordinary" by any reasonable standard. Yet the Foreign Service consistently argued the contrary and resisted attempts to apply section 502B to deny military aid or arms sales in nearly every instance when its application was urged. In other words, giving the Foreign Service any discretion at all is to invite its abuse.

There are, perhaps, some drawbacks to statutes that deny all discretion, such 
as the country-specific legislation. Once such a provision is enacted, the Executive lacks the flexibility to respond quickly to changed conditions. ${ }^{131}$ While Congress has a legitimate role to play in setting basic foreign policy goals, it may be less well equipped to make day-to-day decisions about how best to fulfill those goals in specific cases. Its members, by and large, are not specialists in foreign affairs, and they generally lack the detailed knowledge and expertise required to make careful assessments of human rights practices and United States interests or to balance the benefits and costs of providing military aid or selling arms to a particular government. ${ }^{132}$

For these reasons, a general rule that sets forth basic goals may be preferable to country-specific legislation. Yet the history of section 502B suggests that the creation or tightening of a general rule will produce, by itself, little change in executive behavior. Special implementing mechanisms are required if a substantive rule is to have a direct influence on decisions. Because the career bureaucracy can be expected to abuse the discretion allowed by a general rule, a countervailing center of bureaucratic influence is essential to implementation.

When Congress does provide an implementing mechanism, implementation will still be highly dependent on the attitudes of high political officials. If they are hostile, even a general rule written with a high degree of precision will probably have little impact on executive decisions. The career Foreign Service will exert no influence on political appointees to implement the law, and the Bureau of Human Rights can be effectively neutralized. The Assistant Secretary is a presidential appointee, and a hostile administration can either select someone to fill the position who will not push for implementation or simply leave the post vacant. In such a case, country-specific legislation is the only effective means for Congress directly to influence specific decisions on military aid and arms sales.

Even when a hostile administration disregards section 502B, the statute may serve as an affirmation by Congress that disassociation from repressive governments is a desirable goal of U.S. foreign policy. It reinforces the idea that military ties with such governments can impose considerable costs and should not be pursued unless they are the only available means of securing; especially important national interests. Its existence legitimates efforts by Ciongress to enact legislation that prohibits military aid and arms sales to specific countries. It may also focus the attention of journalists, scholars, and the interested public on executive decisions that would otherwise escape scrutiny.

This examination of attempts by Congress to require the Executive to withhold military aid and arms sales on human rights grounds suggests another important issue: whether withholding is an effective instrument for enforcing adherence to international human rights law. A definitive answer to this question is far from easy to obtain. It may be difficult to determine whether a government has taken positive steps to improve human rights conditions. Changes that are merely "cosmetic" must be distinguished from those which

131 T. FRANCK \& E. WEISBAND, supra note 15, at 32-33.

132 Ibid. 
indicate real improvement. When positive changes do occur, it may be difficult to say whether U.S. actions or other factors were decisive. But the fact that positive changes are lacking does not mean that U.S. actions have been ineffective. Although a targeted government may not have altered current practices, it may be deterred from worse violations. Moreover, regimes other than the immediate target may be influenced by the risk of being denied United States security assistance if they engage in repression. While the impact of withholding security assistance on human rights practices is beyond the scope of this article, it is the logical next question for scholars interested in international human rights. 